\title{
Kachan Yu., Kuznetsov V. \\ Features of operation of wind power stations as an supplementary source of electricity for non-traction consumers of railway electric mains
}

\author{
Качан Ю.Г., Кузнещов В.В. \\ Особливості експлуатації вітроенергетичних станцій як \\ допоміжного постачальника електричної енергії для нетягових \\ споживачів залізничних електромереж
}

Мета. Визначити особливості експлуатації вітроенергетичних станцій як допоміжного постачальника електричної енергії для нетягових споживачів залізничних електромереж та проаналізувати основні чинники, які безпосередньо впливають на застосування вітроенергетичних установок як через випадковий характер вітрового потоку, так і додаткові фрактори, які обумовлені особливостями роботи вищезазначених установок в різних кліматичних умовах.

Методика дослідження грунтується на сучасних методах обчислювальної математики, статистики та аналізу інформації з використанням сучасних комп'ютерних технологій.

Результати дослідження. Необхідність використання відновлюваних джерел енергії в системах електропостачання нетягових споживачів залізничного транспорту очевидно. В умовах постійного зростання цін і тарифрів на електричну енергію в Україні все більша увага приділяється питанням ії економії і пошуку найбільш дешевих і доступних їі альтернативних джерел. Авторами розелянуті питання, пов'язані з можливістю застосування додаткової генерації електричної енергії в системах електропостачання залізничного транспорту шляхом використання вітроенергетичних установок в тому числі і для нетягових споживачів. Проведено аналіз особливостей вітрового потоку в деяких регіонах України, при иьому вимірювання швидкості вітру в місцевостях Запорізької і Дніпропетровської областей було одержано за допомогою компактного датчика швидкості вітру виробництва ТОВ «Микро-Степ-МИС» (Росія). Отриманні значення швидкості вітру були зафріксовані і збережені у иифровому вигляді. Проведено обробку отриманої інформації зазначеного вище приладу. Авторами зроблено висновки, що у разі застосування вітроенергетичних установок в якості додаткового джерела живлення у мережах нетягових споживачів систем електропостачання залізничного транспорту економічно вигідно підключати їх безпосередньо до цих мереж і повністю використовувати всю вироблену ними електроенергію, при цьому скорочуючи на цю величину споживання її з вказаної системи електропостачання.

Наукова новизна полягає у тому, що пропонується використання відновлюваних джерел енераії в системах електропостачання нетягових споживачів залізничного транспорту, зокрема вітрових установок.

Практичне значення. Вровадження вітроенергетичних станцій як допоміжного постачальника електричної енергії для нетягових споживачів залізничних електромереж з метою мінімізації витрат електроенергії.

Ключові слова: відновлювані джерела енергії, якість електричної енергії, вітроенергетична установка, мережі електропостачання залізничного транспорту, нетягові споживачі залізничних електромереж, виробництво електроенергії, швидкість вітру.

Purpose. Identify the features of operation of wind farms as an auxiliary supplier of electricity for non-traction consumers of railway networks and analyze the main factors that directly affect the use of wind farms due to the random nature of wind flow and additional factors due to the above conditions in different climates.

The research methodology is based on modern methods of computational mathematics, statistics and information analysis using modern computer technology.

Findings. The need to use renewable energy sources in the power supply systems of non-traction consumers of railway transport is obvious. Given the constant growth of prices and tariffs for electricity in Ukraine, more and more attention is paid to its savings and the search for the cheapest and most affordable alternative sources. The authors consider issues related to the possibility of using additional generation of electricity in the power supply systems of railway transport through the use of wind turbines, including for non-traction consumers. The analysis of wind flow features in some regions of Ukraine was carried out, and the measurement of wind speed in Zaporizhia and Dnipropetrovsk regions was obtained with the help of a compact wind speed sensor manufactured by Micro-Step-MIS LLC (Russia). The obtained values of wind speed were recorded and stored digitally. The received information of the above device was processed. The authors conclude that in the case of using wind turbines as an additional power source in the networks of nontraction consumers of railway power supply systems it is economically advantageous to connect them directly to these networks and fully use all electricity produced by them, reducing its consumption from this power supply system.

The originality is that the use of renewable energy sources in the power supply systems of non-traction consumers of railway transport, in particular wind turbines, is proposed.

Practical implications. Introduction of wind power plants as an auxiliary supplier of electricity for non-traction consumers of railway power grids in order to minimize electricity costs.

Keywords: renewable energy sources, quality of electric energy, wind power plant, power supply networks of railway transport, non-traction consumers of railway electric networks, electricity production, wind speed.

Introduction

As is known, the use of wind as the most variable and volatile type of energy is currently the most widely

Качан Юрій Григорович - д.Т.Н. профр. ЗНУ

Кузнецов Віталій Вадимович - к.т.н., доц..НМетАУ used [1]. According to [2], in 2019 the total capacity of installed wind farms in the world was $60.4 \mathrm{GW}$, and the total installed capacity of wind energy in the world

Kachan Yu. - Ph.D. prof. ZNU

Kuznetsov V. - Ph.D., Assoc. Prof. NMetAU 
in 2019 reached $651 \mathrm{GW}$. The turnover of the wind energy industry in the world is increasing by $15-30 \%$ compared to each previous year.

As is known from [3,4], the installed capacity of facilities operating on the "green tariff" in Ukraine in 2018 amounted to $2319.2 \mathrm{MW}$ (of which solar power plants - 1427.3 MW, wind power plants - 532.8 MW, others - 202.1 MW). Electricity production with the help of the above facilities amounted to: in 2018 2792.0 million $\mathrm{kW}$-hour (of which SES accounted for 1101.2 million $\mathrm{kW}$-hour; wind farm, 1181.1 million $\mathrm{kW}$-hour; others - 509.7 million $\mathrm{kW} \cdot$ hour).

According to [4], the production of electricity using renewable sources (wind farms, thermal power plants, biomass) for 12 months of 2019 amounted to 5542.2 million $\mathrm{kW}$-hour, which is 2909.5 million $\mathrm{kW}$-hour, or $110.5 \%$ more than for the corresponding period of 2018. And this share is equal to $3.6 \%$ of the total amount of energy produced in Ukraine during this period.

Continuous improvement of wind power plants and technologies of their production opens all new areas of application, including for power supply systems of non-traction consumers of railway transport.

Analysis of literature sources and problem statement

Foreign countries such as Germany, Australia, Great Britain, China, India and Russia have been dealing with the development and introduction of renewable energy sources in the railway power supply system for the last decade. Ukraine is also not far behind global trends.

For instance, locomotives used at Indian electric traction system are based on DC motor drives that have supply of $25 \mathrm{kV}$. Constant increasing demand of electric energy is the main reason for the use of combined or hybrid networks. It is known, that the wind energy used as a renewable energy source that is meshed with the grid and grid network sent power to locomotives of traction line connected by their substation [5]. Nowadays Indian Railways have problems with the limited availability of conventional source and electric networks can use renewable energy sources use as alternative [6].

Paper [7] is devoted to use renewable energy sources (PV panels and wind turbines) for a Spanish high-speed railway line. Currently many foreign countries in their Railways use renewable energy sources as an alternative that traditional energy sources $[8,9]$.

The purpose and objectives of research

While making decisions concerning RES application in the power supply systems for non-traction consumers of railway mains, first it is required to identify the way how to supply the generated power for the consumers. That is possible either in the separated (autonomous) mode for a specific loading share or to all the consumers immediately through the electric main.

It is rather difficult to state what variant is more expedient for the specific case due to the random nature of wind flows (which is the energy resource in this case) and additional uncertainty related to the features of the operation of wind power plants in different climatic conditions. These problems need detailed preliminary analysis during the concept design stage of such implementation. Efficient WPP use in the indicated mains requires knowing and considering all the features of that kind of generation.

Thus, before identifying the possibilities of providing non-traction consumers of electric mains with WPP power, consider the peculiarities of wind flows in some Ukrainian regions. Use the data of wind measuring in these regions obtained with the help of the aforementioned device. The measurements were carried out at the altitude of $50 \mathrm{~m}$ above the earth's surface and recorded with the interval of $\Delta t=10 \mathrm{~min}$.

Fig. 1 represents distributions of the obtained velocities at the distance of $50 \mathrm{~m}$ further south than $\mathrm{Za}$ porizhzhia and $50 \mathrm{~m}$ to the south from Dnipro near the restricted zone of Prydniprovska railway. We can see that in the first case the prevailing velocity is $5-6 \mathrm{~m} / \mathrm{s}$; in the second case, the prevailing velocity is $7-8 \mathrm{~m} / \mathrm{s}$. Winds of more than $15-20 \mathrm{~m} / \mathrm{s}$ velocities at the specified altitude, being the most expedient one for medium-capacity WPP wind motors, are of low probability.

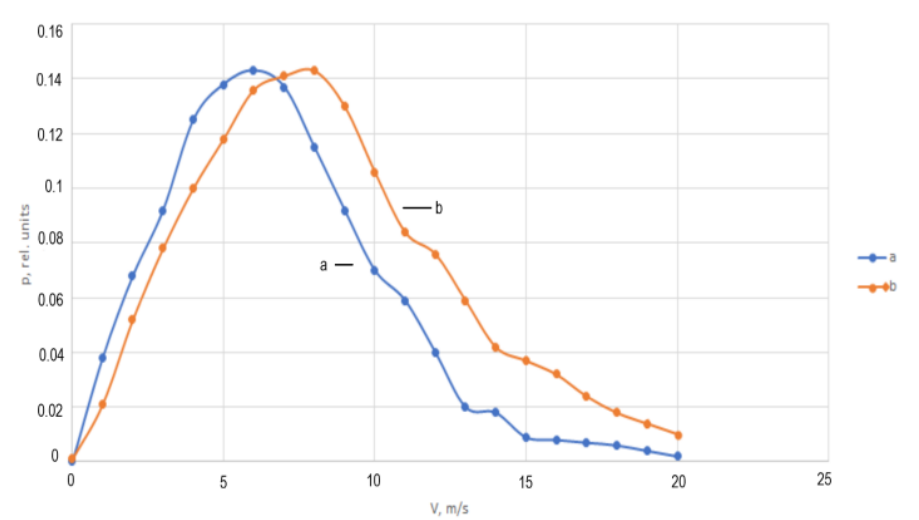

Fig. 1. Distribution of wind velocities near Vasylivka, Zaporizhzhia Oblast (a) and Novomoskovsk, Dnipropetrovsk Oblast (b) according to the results during 2018. 
The mentioned distributions are described with Weibull function with coefficients of altitude $a=6.8612$ and form $b=2.4344$ in the first case and $a=7.6713$ and $\mathrm{b}=2.6311$ in the second case respectively. As for the features of wind velocity changes throughout a year, in terms of the indicated regions it is the same characterized by the dependence shown in Fig. 2.

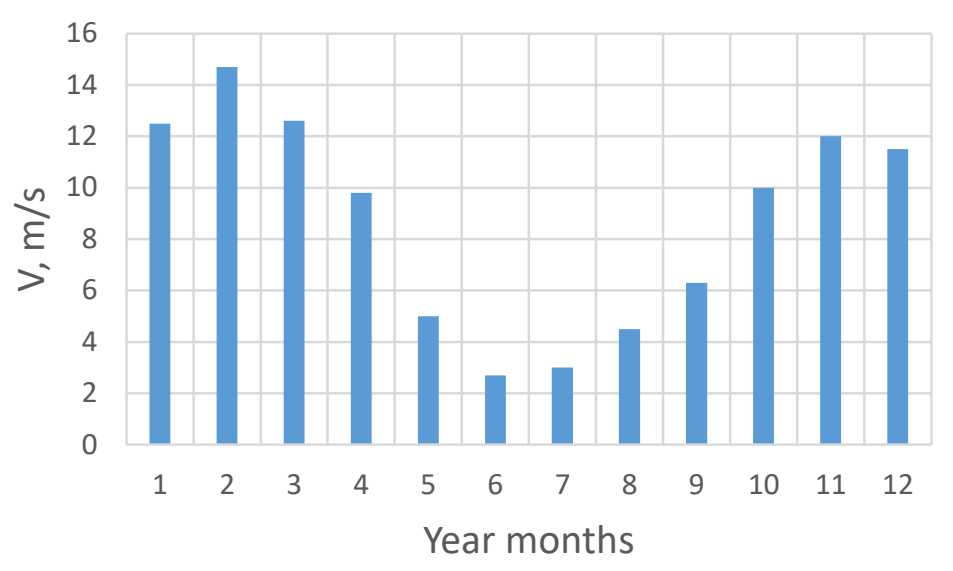

Fig. 2. Annual distribution of the monthly averaged wind velocity characteristic for the areas under consideration

The represented distribution shows that the wind velocity in May-August is almost three times lower than the one observed in Autumn-March. Consequently, while identifying the possibility of autonomous power supply for specific non-traction consumers at the expense of wind power plant energy, it is necessary to consider possible volume of its generation within the period from late spring to early autumn. It means that actually stronger winter winds will not be used at all.
Finally, identify the character of wind velocity distribution throughout a day. Fig. 3 shows the distribution in relative (to maximum) daily values averaged throughout a year and in terms of regions under consideration. We can see that within the indicated interval, wind velocity has clear gaps: from 7 till 11 a.m. and from 6 till 9 p.m. Thus, the share of electric energy generated by WPP within that period is much lower than at night when consumers do not need it so much; in terms of autonomous energy supply, that fact is rather important.

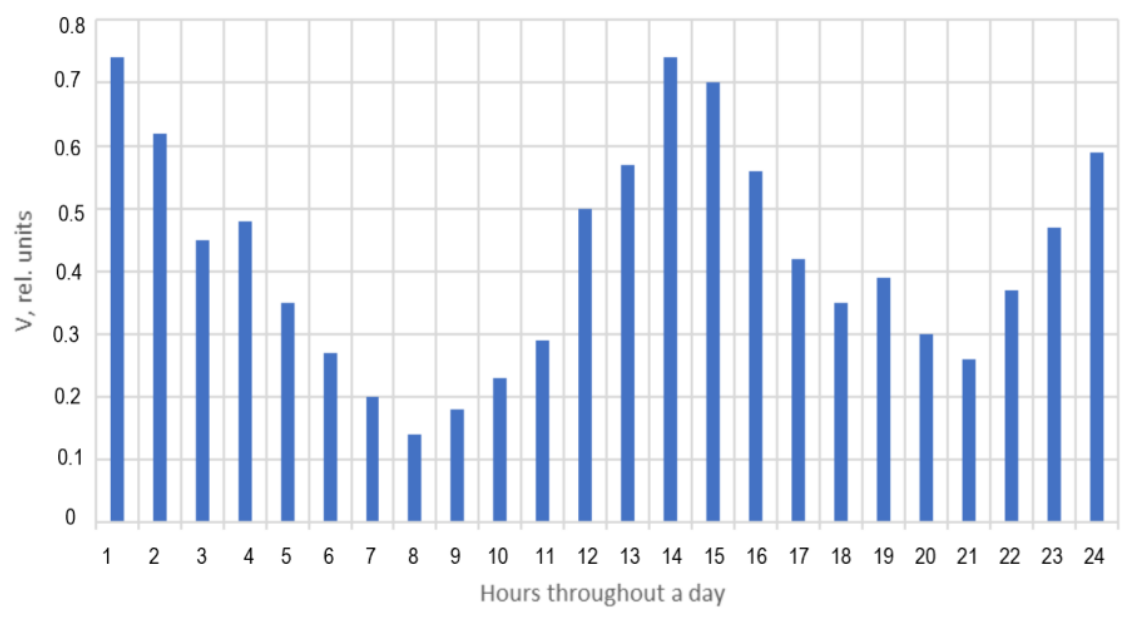

Fig. 3. Distributions of relative wind velocities throughout a day characteristic for the areas under consideration

In this case, it is necessary to use buffer accumulation to store the available electric power. Although today we can do it in different ways, the most universal method is the use of storage batteries which will store extra energy and supply it when generation will not be enough. In other words, when such energy supply system is operating, SB will accumulate some share of electric power generated by RES, coordinating the stochastic nature of its generation with the consumption randomness.
It is obvious that in this case the energy generated by WPP will be distributed as follows:

$$
E_{W P P}=E_{S C}^{W P P}+E_{C h}^{S B},
$$

where $E_{S C}^{W P P}$ is energy share consumed by the WPP loading; and

$E_{C h}^{S B}$ is energy share coming in the SB during charging. 
In this context, general amount of electric energy consumed by the system loading will be as follows:

$$
E_{S C}=E_{S C}^{W P P}+E_{I n}^{S B},
$$

where $E_{I n}^{S B}$ is energy incoming from the SB to consumers.

Having transformed the equations (1) and (2) relative to $E_{S C}^{W P}$ and having compared the obtained results, we will have:

$$
E_{W P P}=E_{S C}+E_{C h}^{W P P}-E_{I n}^{W P P} .
$$

Thus, we find that energy share accumulated in $\mathrm{SB}$ is:

$$
E_{S B}=E_{C h}^{S B}-E_{I n}^{S B} .
$$

It is clear that the energy share accumulated in SB during charging will be equal to:

$$
E_{C h}^{S B}=U_{S B} \cdot I_{C h}^{S B} \cdot \tau_{C h} \cdot \eta_{C h}^{S B},
$$

where $U_{S B}$ is voltage on the SB terminals;

$I_{C h}^{S B}$ is SB charging current;

$\tau_{C h}$ is charging period;

$\eta_{C h}^{S B}$ is efficiency of SB charging.

In this context, following energy share will be taken from SB during the discharging:

$$
E_{I n}^{S B}=U_{S B} \cdot I_{I n}^{S B} \cdot \tau_{I n} \cdot \eta_{I n}^{S B},
$$

where $I_{I n}^{S B}$ is SB discharge current;

$\tau_{I n}$ is discharging period; and

$\eta_{I n}^{S B}$ is efficiency of SB discharging.

Thus, following accumulated energy share is left in the SB in case of its simultaneous charging and discharging:

$$
E_{S B}=U_{S B} \cdot\left(I_{C h}^{S B}-I_{I n}^{S B}\right) \cdot \tau \cdot \eta_{S B},
$$

where $\eta_{S B}$ is generalized SB efficiency; and

$\tau$ is duration of energy conversion in the SB.

At the same time, it is known that [10] the energy accumulated in the SB is determined by the value of voltage $U_{S B}$ and nominal capacity of the battery:

$$
E_{S B}=U_{S B} \cdot C_{S B}^{\text {nom }} \text {. }
$$

Having compared the dependencies (7) and (8), it is understood that the required nominal capacity of buffer SB of that power supply system for non-traction consumers of railway mains should be defined as:

$$
C_{S B}^{n o m}=\left(I_{C h}^{S B}-I_{I n}^{S B}\right) \cdot \tau \cdot \eta_{S B} \text {. }
$$

In this context, the used SB capacity at a specific moment will be equal to:

$$
C=\eta_{S B} \int_{0}^{\tau}\left[i_{S B}^{3}(t)-i_{S B}^{p}(t)\right] \cdot \tau \cdot d t
$$

It is known that the efficiency of a total chargingdischarging cycle, e.g. of lithium accumulation battery, is $0.8 \div 0.9$ [11]. The calculations performed to define $\eta_{S B}=0.8$, taking into account the randomness of the process of energy generation and consumption, have helped to determine the following: for the guaranteed energy supply of the loading with $60 \mathrm{~kW} \cdot \mathrm{h}$ daily needs, the SB should accumulate the energy amount of $104.5 \mathrm{~kW} \cdot \mathrm{h}$. Consequently, total capacity required for that battery with the voltage of $12 \mathrm{~V}$ is:

$$
C_{S B}=\frac{E_{S B}}{U_{S B}}=\frac{104500}{12}=8708.33 \mathrm{~A} \cdot \mathrm{h} .
$$

It is clear that here we need the accumulators designed for much higher voltage, e.g. traction lead-acid ones with the voltage of $120 \mathrm{~V}$.

Thus, the energy, accumulated in the storage battery should exceed the amount necessary for consumption by about 1.7 times. Following calculations have made it possible to define that in terms of further increase in energy consumption, values of that socalled reserve coefficient of SB experience no changes; the value may be recommended for practical use.

Ultimately, consider operational features of WPP which will influence their efficiency in the power supply systems of non-traction consumers. First of all, capacity of any wind power plant is limited by a certain socalled nominal value $P_{n}$ regardless of wind power. Thus, Fig. 4 exemplifies the dependence of WPP characteristic upon wind power for Chinese installation ZH5KW which rated capacity is $5 \mathrm{~kW}$ [12].

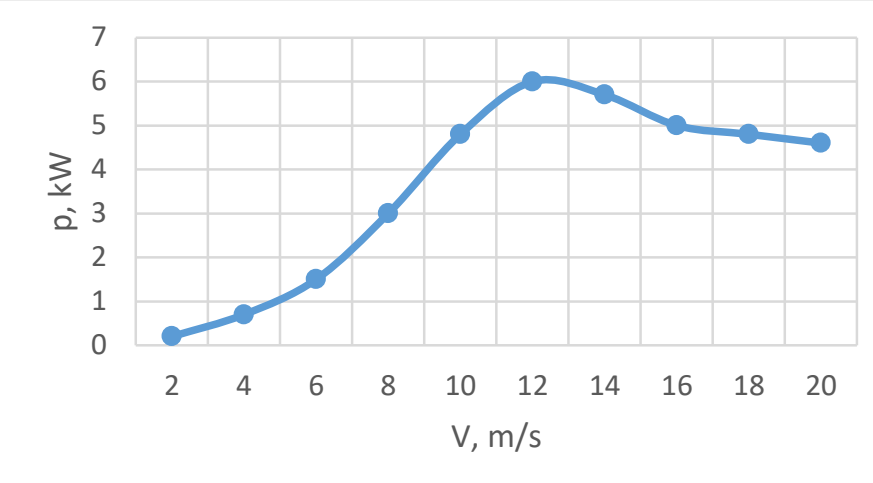

Fig. 4. Dependence of WPP capacity of ZH5KW type upon the wind speed 
Taking into consideration the fact that each wind turbine has its own so-called critical wind speed $V_{\kappa p}$, achieving which it stops [13], WPP model may be set as follows:

$$
P_{W P P}=\left\{\begin{array}{l}
0, \text { if } V \leq V_{0} i V \geq V_{c r} \\
f(V), \text { if } V_{0}<V<V_{N}, \\
P_{n}, \text { if } V_{N}<V<V_{c r}
\end{array}\right.
$$

where $V_{0}$ is initial wind speed required for the WPP operation, $\mathrm{m} / \mathrm{s}$; and

$V_{N}$ is nominal wind speed, $\mathrm{m} / \mathrm{s}$.

In this context, $P_{W P P}=f(V)$ function used to identify WPP capacity in terms of the specified wind speed within $V_{0}<V<V_{N}$ interval may be determined on the expression [14]

$$
P_{W P P}(V)=\frac{1}{2} \rho \cdot V^{3} \cdot F \cdot \eta(V) \cdot \eta_{W P P},
$$

where $\rho$ is wind flow density, $\mathrm{kg} / \mathrm{m}^{3}$;

$\eta(V)$ is coefficient of the wind flow use;

$F$ is rotor swept area, $\mathrm{m}^{2}$; and

$\eta_{W P P}$ is the generalized WPP efficiency.

Generally, rotor swept area is calculated as a circular area

$$
F=\frac{\pi \cdot d^{2}}{4},
$$

where $d$ is diameter of the wind turbine.

In terms of $760 \mathrm{~mm} \mathrm{hg} \mathrm{atmospheric} \mathrm{pressure} \mathrm{and}$ $15^{\circ} \mathrm{C}$ temperature, wind flow $\rho$ is $1.225 \mathrm{~kg} / \mathrm{m}^{3}$.

Fig. 5 shows the simplified dependence of the mentioned WPP upon the wind speed corresponding to expression (11) and using generally for calculations.

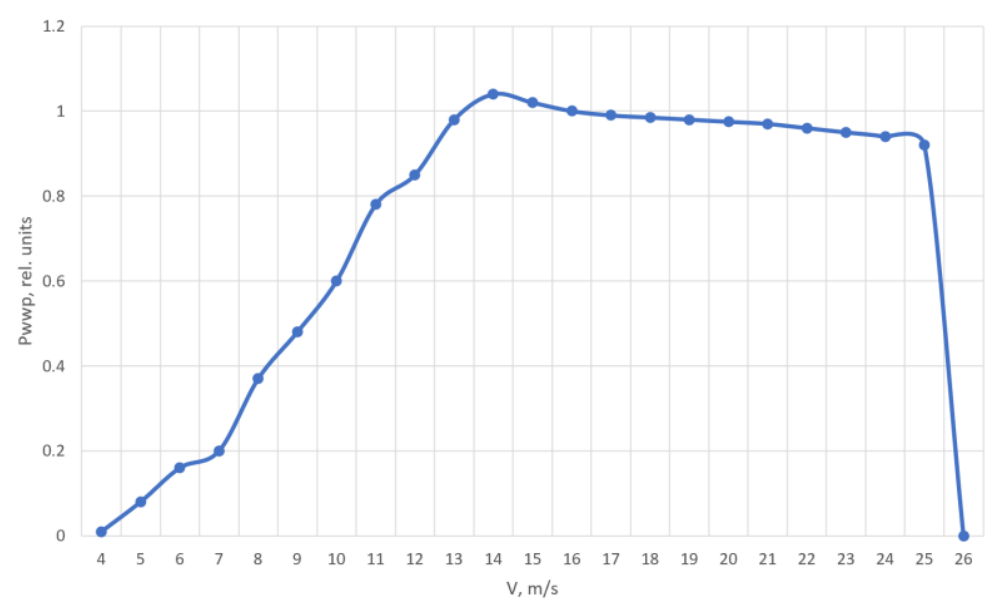

Fig. 5. Simplified analytical dependence of WPP capacity of ZH5KW type upon the wind flow speed

If one compares distribution of wind speeds in the analyzed districts of Zaporizhzhia and Dnipropetrovsk Oblasts (see Fig. 1) with the capacity dependence of the mentioned WPP type (Fig. 5), it becomes understood that it is not expedient to apply such an installation. The matter is that $V_{N} \div V_{c r}$ interval, being the most efficient for it, falls on improbable for the areas with $14 \div 20 \mathrm{~m} / \mathrm{s}$ wind speed. It is obvious that WPP with no more than $12 \mathrm{~m} / \mathrm{s}$ critical wind speed $V_{c r}$ should be applied in this case.

All this suggests that to generate the required electric energy amount irrespective of a season, the wind turbine should involve several installations with small value of critical speed rather than one more powerful WPP which would resist all possible windings being typical for the terrain. Krasnodon WPS can support the idea since it involves ten different installa- tions of FL 2500 type [15]. Fig. 6 demonstrates its annual electric energy generation [16].

The dependence explains that the WPS generates more energy in summer to compare with winter when it is more needed. Moreover, the terrain is characterized by rather strong winds. Thus, the power station does not use the available resource in full.

If electric power sources are developed by powerful WPPs, which critical speed rather high as for the winds in the areas of their location, then it will result in the decreased efficiency of the installation as well as in the necessity to have more consumers who need the excess of the generated electric energy. It means that they have to work for the shared mains rather than operating autonomously. 


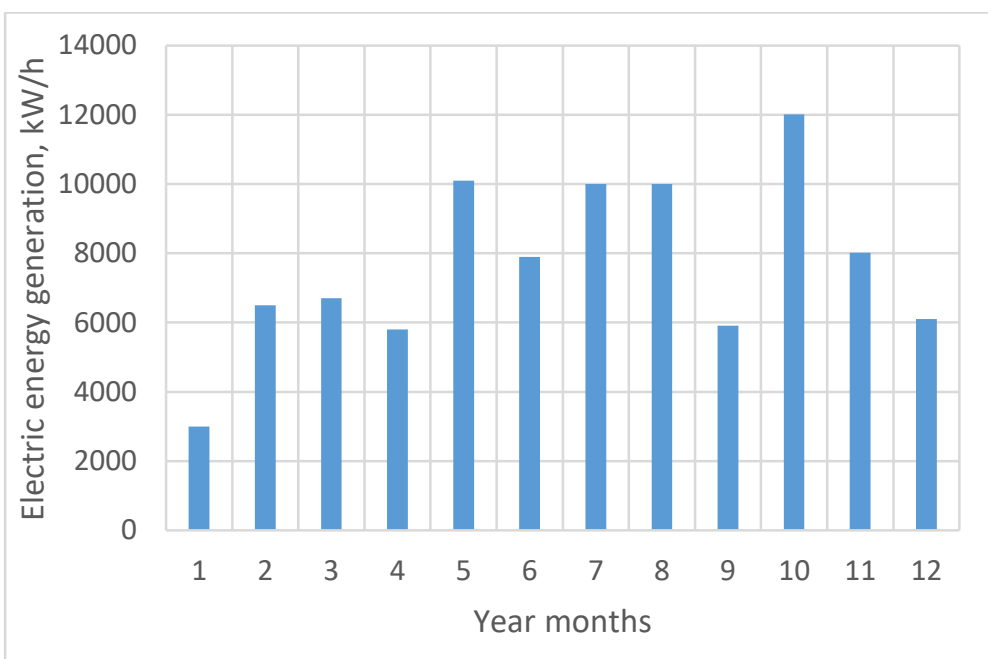

Fig. 6 Dynamics of the electric energy generation by Krasnodon WPS in 2018

Hence, if wind plants are used in power supply networks of non-traction consumers of railway mains, it is more expedient to connect them directly to the networks and consume the whole energy, generated by them, while decreasing its consumption by the value from the mentioned electric power supply system. In this context, it is possible to improve efficiency of the extra generation sources by means of introduction of different types of wind turbines which would provide simultaneously maximum coefficient of their annual use and take into consideration the features of wind speed distribution within a specific area (i.e. apply maximally the available energy resource). The problem should be considered as a separate optimization task while designing such energy sources.

\section{REFERENCES}

1. Shevlyugin M.V., Zhumatova A.A. Possibility of using renewable energy sources in the traction power supply system of railways // Science and technology of transport. No. 4, 2008. Pp. 25-28.

2. In 2019, the installed capacity of the global wind energy grew by $19 \%$.- [Electronic resource]: https://kosatka.media/category/vozobnovlyaemaya-energia/news/v-2019-godu-ustanovlennaya-moshchnostmirovoy-vetroenergetiki-vyrosla-na-19

3. Integrated report 2018. Overview of industries and macroeconomic indicators of Ukraine. 01. Electricity market. [Electronic resource]: https://dtek.com/content/files/rynok-elektroenergi.pdf

4. Electricity production in Ukraine. - [Electronic resource]: https://kosatka.media/uk/category/elektroenergiya/analytics/proizvodstvo-elektroenergii-v-ukraine-u-vieznachitelnyy-rirost.

5. S. K. Bade and V. Kulkarni. Use of Renewable energy in performance enhancement of Indian Traction Power Supply System, 2018 International Conference on Smart Electric Drives and Power System (ICSEDPS), Nagpur, 2018, pp. 111-116, doi: 10.1109/ICSEDPS.2018.8536056.

6. L. Singh, C. Vaishnav and V. Shrivastava. Performance Analysis of Hybrid Network of Indian Traction Power System Using Renewable Energy Sources, 2016 International Conference on Micro-Electronics and Telecommunication Engineering (ICMETE), Ghaziabad, 2016, pp. 611-615, doi: 10.1109/ICMETE.2016.101.

7. J. A. Aguado, A. J. Sánchez Racero and S. de la Torre. Optimal Operation of Electric Railways With Renewable Energy and Electric Storage Systems, in IEEE Transactions on Smart Grid, vol. 9, no. 2, pp. 993-1001, March 2018, doi: 10.1109/TSG.2016.2574200.

8. E. Hotchkiss and C. Larney, The Use of Renewable Energy to Provide Power to California Railway California High Speed Railway Authority, Dec. 2011, [online] Available: http://www.hsr.ca.gov/.

9. Gediminas Vaičiūnas, Gintautas Bureika and Lionginas Liudvinavičius, "Expedience of Applying Solar and Wind Hybrid Power-Plants in Railway Infrastructure Objects", 9th International Scientific Conference Transbaltica, 2015.

10. Budko V.I. Development of a mathematical model of the autonomous charging station of electric cars from wind power plants / V.I. Any // Renewable Energy. - 2017. -№ 3. - Pp. 6-13.

11. John Sun «Car Battery Efficiencies" [Electronic resource]: http://large.stanford.edu/courses/2010/ph240/sunl/

12. Official site BYD in Ukraine [Electronic resource]: http://byd.iproaction.coni/ua/vehicle/e6.htm

13. Diaf S., Belhamel M, Haddadi M., Louche A. A methodology for optimal sizing of autonomous hybrid PV/wind system/S.Diaf, M.Belhamel, M. Haddadi, A. Louche// Energy Policy, Volume 35. Issue 11, pp. 5708-5718, 2007.

14. Kudrya CO., Budko B.I. Introduction to the specialty. Unconventional and renewable energy sources: Electronic course of lectures / S.O. Кудря, B.I. Budko / - Kyiv: National Technical University of Ukraine (KPI). 2013.- 360 p.

15. Open data portal. [Electronic resource]: http://data.gov.ua

16. Budko V.I. Autonomous power units based on renewable energy sources with different energy storage systems / V.I. Budko // Renewable energy. -2015. - №2. - Pp.21-25. 